\title{
Adopsi Inovasi Probiotik pada Kolam Dempond Pendederan Ikan Mas (Cyprinus carpio) di Kelompok "Mina Pojok Jaya" Kecamatan Subang
}

\author{
[Adoption Of Probiotic Innovations In Dempond Ponds For Carp Nursery In The \\ Mina Group In Jaya Corner Subang Sub-district]
}

Nursahla, Tatty Yuniarti, Herry Maryuto, Dedi Sutarso

Sekolah Tinggi Perikanan Jurusan Penyuluhan Perikanan Jalan Cikaret No 02, Bogor Selatan, Kota Bogor

\begin{abstract}
Abstrak
Budidaya ikan mas merupakan salah satu kegiatan unggulan perikanan di Kecamatan Subang. Produksi budidaya tersebut dapat ditingkatkan dengan menggunakan probiotik. Penyuluhan merupakan cara dalam rangka untuk menginformasikan teknologi baru seperti probiotik sehingga sasaran penyuluhan dapat mengadopsi teknologi baru tersebut. Tujuan penelitian adalah untuk melakukan penyuluhan menggunakan metoda demonstrasi cara membandingkan tingkat produksi pendederan ikan mas menggunakan probiotik dan tanpa probiotik, dan mengevaluasi kemampuan adopsi inovasi teknologi probiotik pada pendederan ikan mas. Penelitian adopsi inovasi ini dilakukan di Kecamatan Subang, kelurahan Sukamelang dengan jumlah responden sebanyak 10 orang yang ada di Kelompok Mina Pojok Jaya. Penelitian adopsi inovasi ini menggunakan perlakuan probiotik atau suplemen, yaitu probiotik viterna plus yang diaplikasikan di dalam pakan untuk diberikan pada ikan mas sebagai suplemen penambah nafsu makan ikan sehingga dapat mempercepat pertumbuhan ikan mas. Hasil penelitian menunjukkan bahwa kegiatan adopsi inovasi ini dapat meningkatkan produksi pembudidaya dengan jumlah tebar yang sama yaitu 1.000 .000 ekor larva memiliki jumlah produksi yang berbeda yaitu yang menggunakan probiotik yaitu menghasilkan produksi sebanyak $2.000 \mathrm{~kg}$ sedangkan yang tidak menggunakan probiotik produksi yang dihasilkan hanya $1.500 \mathrm{~kg}$. Terdapat $40 \%$ dari jumlah responden yang sudah mulai menerapkan inovasi yang telah diberikan pada minggu terakhir kegiatan dempond dilakukan.
\end{abstract}

Kata kunci : evaluasi penyuluhan, penyuluhan perikanan, produksi perikanan budidaya

\section{Abstract}

Goldfish cultivation is one of the leading fisheries activities in Subang District. The cultivation production can be increased by using probiotics. Counseling is a way in order to inform new technologies such as probiotics so that targets can adopt these new technologies. The research objective is to conduct counseling using demonstration methods of comparing production levels of carp nursery using probiotics and without probiotics, and evaluating the ability of adoption of technological innovations in probiotic carp breeding. This innovation adoption study was conducted in Subang Subdistrict, Sukamelang sub-district with 10 respondents in the Mina Pojok Jaya Group. This innovation adoption research uses a probiotic or supplement treatment, namely viterna plus probiotics which are applied in the feed to be given to carp as a supplement to increase the appetite of fish so as to accelerate the growth of carp. The results showed that the adoption of this innovation can increase the production of farmers with the same stocking amount of 1.000.000 larvae that have different amounts of production that uses probiotics that produce as much as $2.000 \mathrm{~kg}$ while those who do not use probiotics produce only $1.500 \mathrm{~kg}$. There are $40 \%$ of the target number that has begun to apply the innovations that have been given in the last week of the dempond activities. 


\section{PENDAHULUAN}

Budidaya ikan diseluruh dunia menghadapi permasalahan yang sama yaitu turunnya mutu lingkungan budidaya hal ini disebabkan akumulasi limbah pakan dari budidaya yang telah berjalan dalam waktu lama. Iribarren et al. (2012) menyatakan bahwa penggunaan probiotik menjadi solusi internal untuk menghasilkan pertumbuhan dan efisiensi pakan yang optimal, mengurangi biaya produksi dan pada akhirnya dapat mengurangi biaya beban lingkungan karena akumulasi limbah diperairan.

Penggunaan probiotik dalam budidaya bertujuan untuk menjaga keseimbangan mikro dan pengendalian patogen dalam saluran air, serta lingkungan perairan melalui proses biodegradasi. Ada dua macam cara pengaplikasian probiotik yaitu melalui lingkungan air media budidaya dan melalui oral yaitu dicampur dalam pakan. Aplikasi cara kedua dapat meningkatkan kualitas pakan dengan menambahkan bahan aditif berupa probiotik yang berisi mikro pengurai didalam pakan yang berfungsi untuk memperbaiki kualitas pakan dengan cara penguraian dapat meningkatkan pencernaan ikan
(Mansyur dan Tangko, 2008). Beberapa jenis bakteri-bakteri probiotik yang telah banyak diaplikasikan pada budidaya air tawar, air payau dan air laut iantaranya yang sering digunakan yaitu Basilus sp. (Boonthai, Vuthiphandchai dan Nimrat, 2011).

Budidaya ikan mas (Cyprinus carpio) saat ini masih banyak dilakukan secara tradisional di kolam tanah akan tetapi sudah memanfaatkan pakan buatan untuk memacu pertumbuhannya. Peningkatan pertumbuhan pada ikan saat ini masih terus dilakukan dengan mengefisienkan pakan sehingga limbah budidaya seperti feses dan sisa pakan menurun. Penelitian yang mengaplikasikan probiotik pada ikan mas masih sedikit terutama untuk meningkatkan pertumbuhan dan efisiensi pakan mas. Pemberian probiotik tersebut diharapkan dapat masuk ke dalam saluran pencernaan ikan mas sehingga dapat memperbaiki kemampuan ikan dalam mencerna makan. Irianto (2003) menyatakan bahwa probiotik dapat mengatur lingkungan mikrobia pada usus, menghalangi mikroorganisme patogen dalam usus dengan melepas enzim-enzim yang dapat membantu 
proses pencernaan makanan. Salah satu bakteri yang diyakini mampu untuk meningkatkan daya cerna pada ikan yaitu Bacillus sp.

Hanan (2017) menyatakan bahwa inovasi dalam penyuluhan perikanan terkait dengan proses teknologi baru yang di sampaikan ke sasaran penyuluhan yaitu pelaku utama perikanan. Aspek yang terkait dengan proses adopsi inovasi adalah teknologi inovasi dan rentang waktu, daerah atau sasaran. Suatu teknologi dapat dianggap suatu inovasi di suatu daerah atau waktu tertentu, tetapi tidak inovasi lagi di daerah atau waktu yang lain. Kecepatan tahap menerapkan suatu inovasi yang disampaikan merupakan fenomena menarik untuk diamati, dikarenakan banyak faktor-faktor yang mempengaruhi hal tersebut. Faktor-faktor yang mempengaruhi tersebut diantaranya adalah faktor sugesti (pengaruh atau kepercayaan), identifikasi (penelaahan), dan juga faktor imitasi (peniruan), dan ciri-ciri dari inovasi yang disampaikan, serta gencarnya promosi dari inovasi tersebut. Inovasi pembanding juga merupakan bagian dari pertimbangan dalam menerapkan satu inovasi. Penggunaan probiotik untuk meningkatkan produksi ikan, kecepatan menerapkan tergantung dari perlakuan yang dilakukan oleh suatu sistem sosial.
Penelitian ini bertujuan untuk melakukan penyuluhan menggunakan metode demonstrasi cara membandingkan tingkat produksi pendederan ikan mas menggunakan probiotik dan tanpa probiotik, dan mengevaluasi kemampuan adopsi inovasi teknologi probiotik pada pendederan ikan mas. Penelitian ini diharapkan dapat memberikan manfaat dalam hal: (1) memberikan konstribusi bagi pengembangan ilmu dan teknologi terutama yang berkaitan dengan inovasi teknologi probiotik; (2) inovasi teknologi probiotik ini diharapkan dapat diadopsi oleh pelaku usaha perikanan di Kelompok "Mina Pojok Jaya" sebagai inovasi baru yang diterapkan di kelompok tersebut.

\section{BAHAN DAN METODE}

Penelitian adopsi inovasi pada kolam dempond pendederan ikan mas ini dilakukan pada Kelompok Mina Pojok Jaya di Kecamatan Subang Kelurahan Sukamelang Kabupaten Subang Provinsi Jawa Barat. Penelitian dilakukan lebih kurang selama tiga bulan yaitu dari tanggal 11 Maret sampai tanggal 24 Mei 2019. Sasaran penyuluhan yaitu responden dalam penelitian ini adalah anggota Kelompok Mina Pojok Jaya yang berjumlah 10 orang rumah tangga perikanan (RTP). Pemilihan 10 orang responden berdasarkan metoda purposive sampling, yaitu pemilihan 
berdasarkan keaktifan anggota dalam melaksanakan usaha budidaya pendederan ikan mas.

Penelitian penyuluhan untuk mengamati adopsi inovasi aplikasi probiotik pada pendederan ikan mas, menggunakan metoda kolam demonstrasi (dempond). Pendederan ikan mas ini menggunakan pakan dengan kadar protein 38-42\%. Probiotik yang digunakan yaitu probiotik/suplemen viterna plus dengan dosis $15 \mathrm{~mL} . \mathrm{kg}^{-1}$ pakan. Hal ini sesuai dengan pendapat Putri, Hasan, dan Haetami (2012) menyatakan bahwa pemberian probiotik dengan kadar protein $15 \mathrm{~mL} . \mathrm{kg}^{-1}$ pakan memberikan hasil terbaik terhadap laju pertumbuhan harian dan rasio konversi pakan benih ikan mas yaitu sebesar 2,76 $\%$ dan 1,48 \%. Metode perbandingan digunakan untuk membandingkan perlakuan kolam dengan menggunakan pakan yang ditambah probiotik (kolam A) dan kolam pakan tanpa probiotik (kolam B). Perbedaan pertumbuhan di antara kedua kolam diharapkan dapat membuat pelaku utama perikanan mengadopsi dengan cepat inovasi yang diberikan.

Evaluasi kegiatan dempond pendederan ikan mas menggunakan probiotik meliputi aspek pengetahuan, sikap, keterampilan dengan instrumen berupa kuisioner yang diberikan pada awal (pre-test) dan akhir (post-test) yang telah divalidasi. Data yang dihasilkan diolah dan ditampilkan menggunakan tabel dan grafik. Data yang dikumpulkan terdiri dari data primer dan data sekunder. Data primer dikumpulkan dengan wawancara kepada sasaran penyuluhan. Data sekunder diperoleh dari wawancara secara mendalam dengan ketua kelompok, penyuluh perikanan, dan kepala desa.

\section{HASIL DAN PEMBAHASAN \\ Hasil}

Kecamatan Subang merupakan salah satu dari 30 Kecamatan yang ada di Kabupaten Subang dengan luas wilayah $1.894 \mathrm{~km}^{2}$. Dengan jumlah penduduk 133.142 jiwa dengan jumlah pelaku utama yang sudah terdata oleh penyuluh perikanan sebanyak 69 RTP dengan jumlah kelompok sebanyak tiga kelompok perikanan yang mayoritasnya bergerak pada segmen usaha pendederan ikan mas. Salah satu kelompok pembudidaya yang aktif adalah Kelompok Mina Pojok Jaya. Anggota kelompok ini menjadi responden pada penelitian ini. Karakteristik responden pada penelitian ini dapat dilihat pada Tabel 1.

Lokasi usaha budidaya ikan di Kelurahan Sukamelang berada jauh dari kebisingan dan getaran kendaraan, tempat lalu lalang orang, bebas banjir dan sesuai dengan tata ruang wilayah. Lokasi usaha juga jauh dari limbah pabrik 
maupun limbah rumah tangga yang dapat mencemari sumber air hingga menyebabkan kematian pada ikan budidaya. Lokasi usaha budidaya ikan tersebut dekat dengan sumber air yang ketersediannya bisa terjamin sepanjang tahun serta debitnya cukup.

Kegiatan adopsi inovasi teknologi probiotik pada usaha pendederan ikan mas dilaksanakan karena rendahnya produksi benih ikan mas di Kelompok
Mina Pojok Jaya. Rendahnya produksi benih terjadi akibat rendahnya pengetahuan, sikap dan keterampilan pembudidaya akan inovasi teknologi perikanan seperti penggunaan probiotik pada usaha budidaya perikanan. Hanan (2017) menyatakan bahwa aplikasi probiotik diterapkan mulai dari persiapan kolam hingga masa pemeliharaan baik melalui pakan maupun melalui media budidaya setempat. Probiotik

Tabel 1. Karakteristik responden penyuluhan perikanan

\begin{tabular}{llcc}
\hline No & Anggota Kelompok & Usia (Tahun) & Pendidikan \\
\hline 1 & Rusmana & 60 & SMA \\
2 & Sinta Nur & 35 & S1 \\
3 & Aji Saprudin & 45 & SMA \\
4 & Samsu & 49 & SMP \\
5 & Kusnadi & 40 & SMA \\
6 & Taslim & 50 & SD \\
7 & Doni & 44 & SMP \\
8 & Darmo & 39 & SMA \\
9 & Asep & 50 & SMP \\
10 & Endro & 40 & SMA \\
\hline
\end{tabular}

Keterangan : $\mathrm{SD}=1, \mathrm{SMP} / \mathrm{SLTP}=3, \mathrm{SMA} / \mathrm{SLTA}=5$, Perguruan Tinggi $=1$

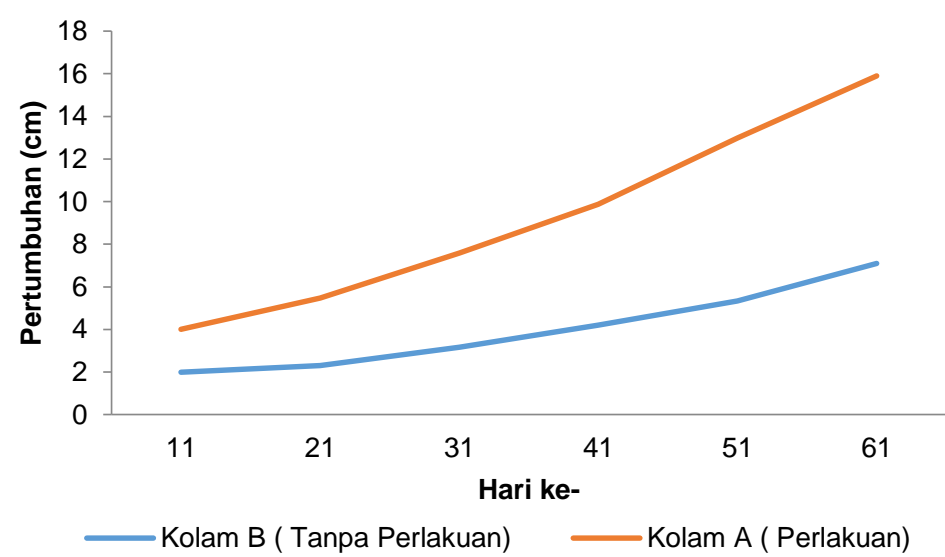

Gambar 1. Monitoring pertumbuhan panjang pendederan ikan mas 


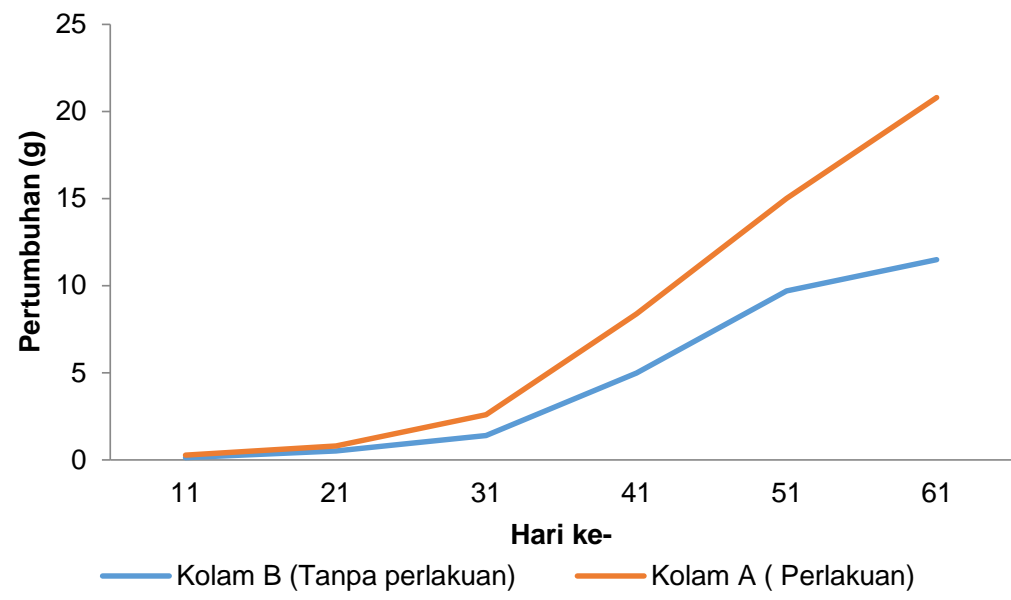

Gambar 2. Monitoring pertumbuhan berat pada pendederan ikan mas

dicampurkan ke dalam pakan, dengan cara mengencerkan probiotik cair kemudian mencampur probiotik encer ke dalam pakan secara merata. Campuran kemudian ditunggu sebentar sebelum diberikan pada ikan. Pemberian probiotik dengan aplikasi di dalam pakan dapat meningkatkan bobot tubuh ikan lebih tinggi dibandingkan dengan pakan tanpa probiotik. Hasil penelitian pemberian probiotik pada ikan mas di kolam dempond Kelompok Mina Pojok Jaya disajikan pada Gambar 1.

Pada Gambar 1 dapat disimpulkan bahwa tingkat pertumbuhan panjang (cm) pendederan ikan mas menggunakan probiotik (kolam A) terlihat jauh lebih cepat pertumbuhannya dibandingkan pada ikan yang tidak menggunakan probiotik (kolam B). Demikian pula dengan pertumbuhan berat $(\mathrm{g})$ ikan mas yang diberi pakan dengan probiotik (kolam A) lebih cepat naik berat tubuh ikan dibandingkan dengan ikan mas yang diberi pakan tanpa probiotik (kolam B). Pertumbuhan berat (g) ikan mas perlakuan pakan dengan dan tanpa probiotik dapat dilihat pada Gambar 2 di bawah ini.

Pengelolaan kualitas air perlu dilakukan dalam kegiatan budidaya karena pakan komersial dalam budidaya menyebabkan pencemaran lingkungan dan meningkatkan kemungkinan pada wabah penyakit, oleh karena itu manajemen kualitas air sangat penting dalam sistem akuakultur. Tujuan dari manajemen kualitas air adalah untuk menyediakan lingkungan yang nyaman dan memenuhi persyaratan optimal untuk budidaya organisme. Penerapan pengelolaan kualitas air seperti sirkulasi dan resirkulasi dapat meningkatkan nilai performa biologis serta kualitas media pemeliharaan sehingga dapat meningkatkan performa produksi ikan 


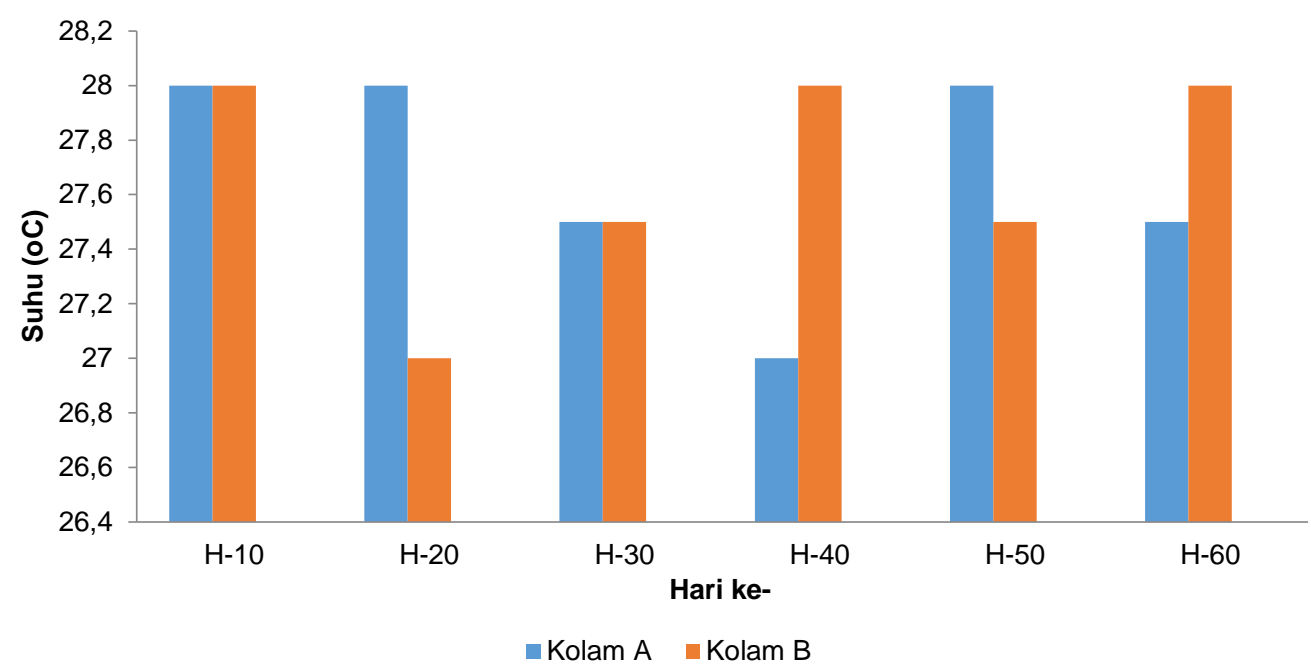

Gambar 3 Pengukuran suhu pada kolam A dan kolam B

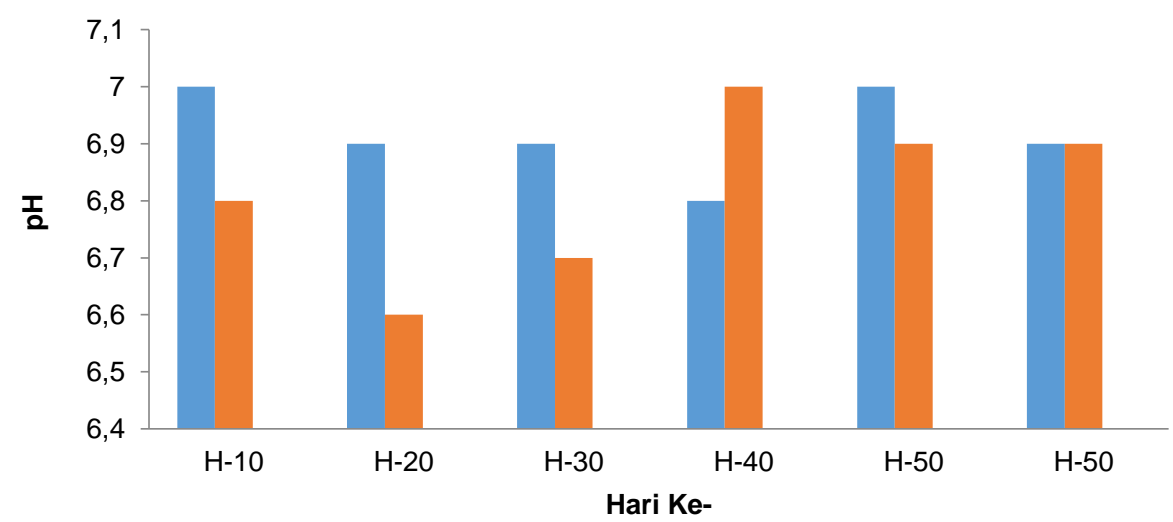

Kolam A

Kolam B

Gambar 4. Pengukuran pH pada kolam A dan kolam B

(Primaningtyas, Hastuti dan Program, 2015). Berdasarkan pernyataan tersebut maka dilakukan sirkulasi terus menerus pada kegiatan dempond sehingga air selalu berganti dan oksigen tercukupi, dan dilakukan monitoring kualitas air satu kali setiap 10 hari selama pemeliharaan. Parameter kualitas air yang diamati yakni $\mathrm{pH}$ dan suhu. Grafik pengamatan kualitas air selama pemeliharaan pada kolam A dan B dapat dilihat pada Gambar 3 dan 4 di atas.

Parameter kualitas air suhu pada kolam A rata-rata $27,6{ }^{\circ} \mathrm{C}$ dan $\mathrm{pH}$ ratarata sebesar 6,9 sedangkan pada $B$ diperoleh suhu rata-rata $27,6^{\circ} \mathrm{C}$ dan $\mathrm{pH}$ rata-rata 6,8 . Tingkat suhu pada kedua kolam masih dalam standar toleransi, karena masih sesuai dengan SNI 016484.4-2000 bahwa suhu air pada 
Tabel 2. Perbandingan hasil dempond pendederan ikan mas menggunakan perlakuan probiotik dan tidak menggunakan probiotik

\begin{tabular}{|c|c|c|c|}
\hline No & Parameter & Kolam A & Kolam B \\
\hline 1 & Luas Kolam (m²) & 4.200 & 4.200 \\
\hline 2 & Kedalaman Air (cm) & 150 & 150 \\
\hline 3 & Lama Pemeliharaan (hari) & 60 & 60 \\
\hline 5 & Jumlah pupuk (kg) & $\begin{array}{l}\text { Urea }=30 \\
\text { Tsp }=10\end{array}$ & $\begin{array}{l}\text { Urea }=30 \\
\text { Tsp }=10\end{array}$ \\
\hline 6 & Ukuran tebar awal & Larva umur 7 hari & Larva umur 7 hari \\
\hline 7 & Padat Tebar (ekor.m²) & 238 & 238 \\
\hline 8 & Tebar (ekor) & 1.000 .000 & 1.000 .000 \\
\hline 9 & Jenis Pakan & $\begin{array}{c}\text { Pakan Pellet } \\
\text { (protein 38-42\%) }\end{array}$ & $\begin{array}{c}\text { Pakan Pellet (protein } 38 \\
42 \% \text { ) }\end{array}$ \\
\hline 10 & Persentase Pakan (\%.hari-1) & $3-5 \%$ & Ad libitum \\
\hline 11 & Jumlah Pakan Total (kg) & 2.000 & 2.000 \\
\hline 12 & Jumlah Panen (ekor) & 200.000 & 150.000 \\
\hline 13 & Produksi (kg) & 2.000 & 1.500 \\
\hline 14 & Produktivitas Akhir (kg.m²) & 0,4 & 0,35 \\
\hline 15 & Rata-rata bobot panen.ekor ${ }^{-1}(\mathrm{~g})$ & 11,5 & 9,3 \\
\hline 16 & SR (\%) & 20 & 15 \\
\hline 17 & Konversi pakan (FCR) & 1 & 1,3 \\
\hline 18 & Jumlah probiotik viterna plus $(\mathrm{mL})$ & 3.000 & - \\
\hline 19 & Mortalitas (\%) & 80 & 85 \\
\hline
\end{tabular}

kegiatan budidaya ikan mas sebesar 25$30^{\circ} \mathrm{C}$. pH air kolam A 6,9 dan pH kolam B sebesar 6,8 pada hal ini $\mathrm{pH}$ pada $\mathrm{A}$ dan kolam $B$ sudah sesuai dengan acuan $\mathrm{SNI}$ 01-6484.4-2000 bahwa pH air 6,5-8,5.

Pemanenan dilakukan pada pagi hari sekitar pukul 08.00 sampai dengan selesai. Cara pemanenan yaitu dengan menyurutkan air sedikit kemudian dipasang happa di tengah-tengah kolam dekat dengan saung yang berada di tengah kolam. Ikan terbiasa makan di tempat ini, sehingga pada saat panen dipasang happa kemudian diberi pakan di tengahnya untuk memancing ikan berkumpul setelah ikan berkumpul kemudian happa diangkat ke pinggir kolam. Proses selanjutnya adalah grading kemudian penimbangan ikan untuk dipasarkan. Hasil dempond pendederan ikan mas pada kedua kolam dapat dilihat pada tabel di bawah ini.

Berdasarkan hasil demonstrasi kolam di atas dapat diketahui bahwa 


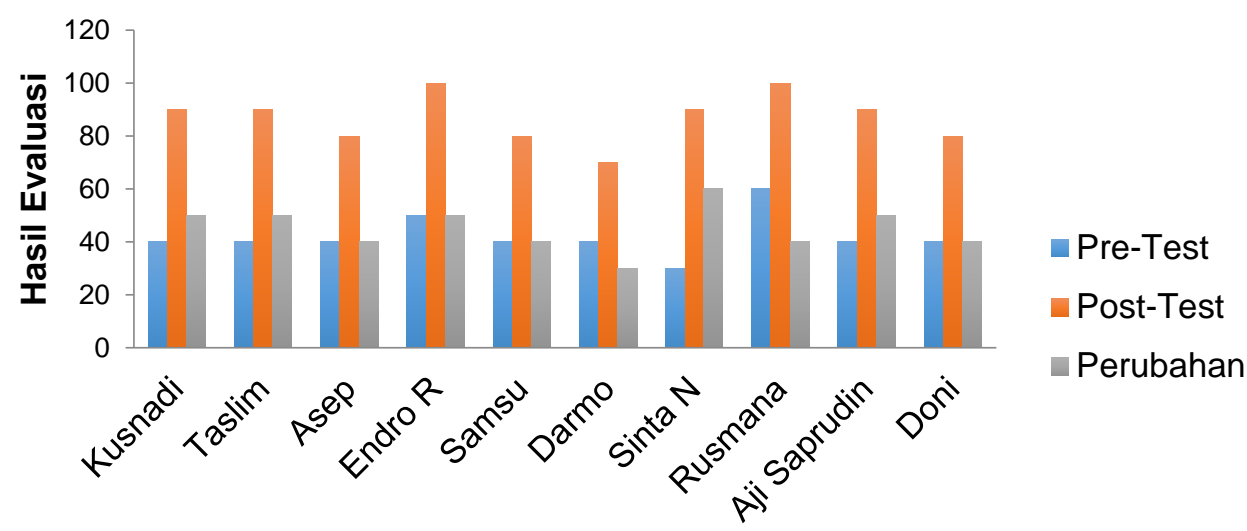

Nama Responden

Gambar 5. Diagram evaluasi pengetahuan dempond pendederan ikan mas

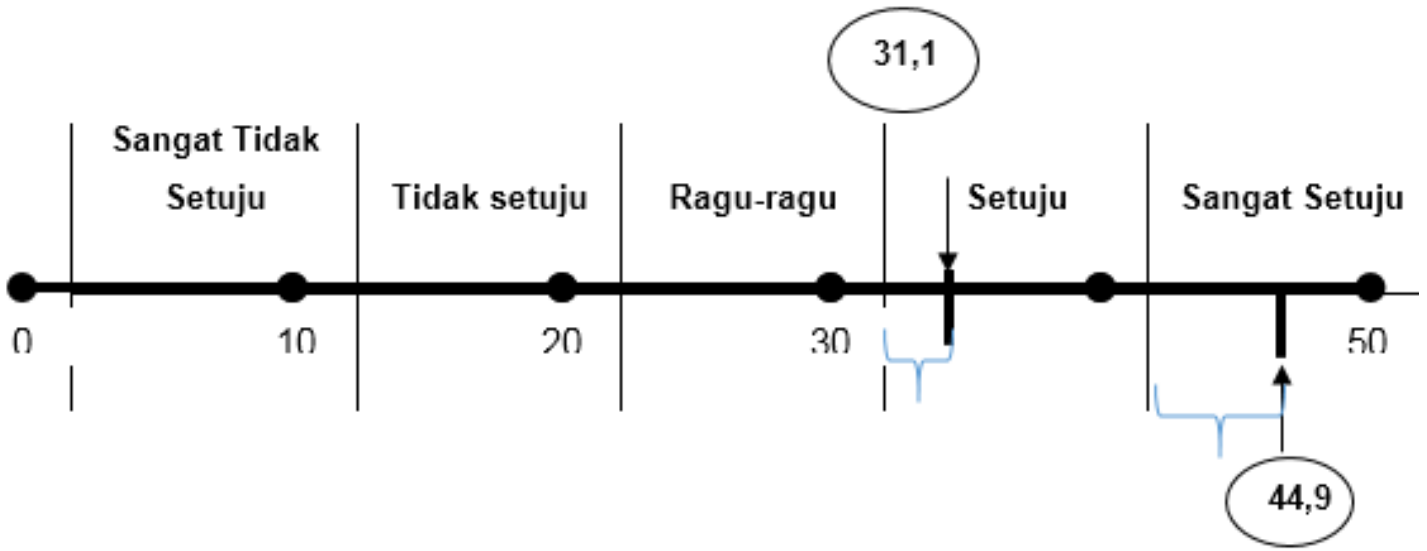

Gambar 6. Diagram kontinum aspek sikap

kolam A memiliki keunggulan lama yaitu budidaya tanpa probiotik yang dibandingkan dengan kolam B. selama ini mereka kerjakan dan Keunggulan tersebut antara lain produksi teknologi baru yaitu budidaya pada kolam A lebih tinggi dibandingkan menggunakan pakan yang ditambah dengan kolam B. Konversi pakan pada dengan probiotik. Demonstrasi cara lebih kolam A lebih rendah yaitu 1 efektif daripada pertemuan umum pada dibandingkan dengan konversi pakan kegiatan penyuluhan (Ningsih, Nalefo pada kolam B yaitu 1,3. Pada dan Wunawarsih, 2019).

penyuluhan melalui demonstrasi cara,

Hasil evaluasi aspek pengetahuan responden terlibat dalam kegiatan responden setelah melaksanakan penelitian dan melihat hasil perbandingan teknologi budidaya yang demonstrasi dengan tema penggunaan probiotik pada pendederan ikan mas, 


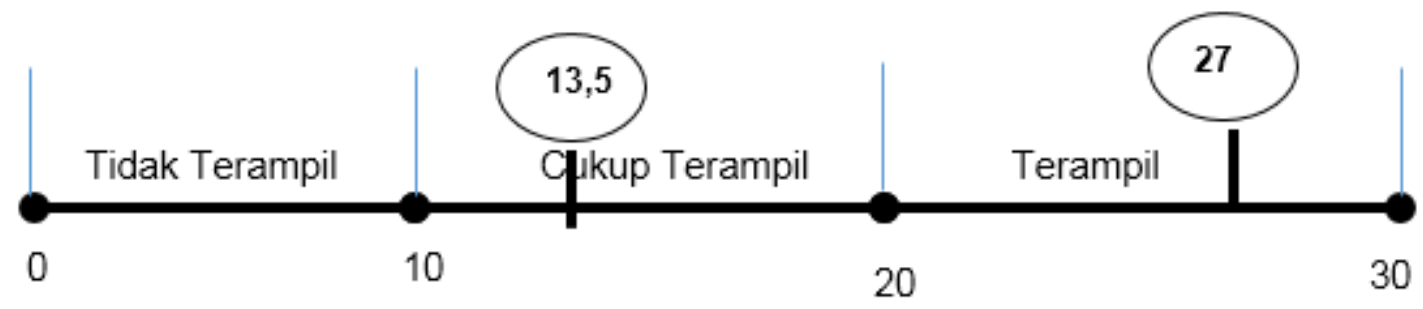

Gambar 7. Diagram kontinum aspek keterampilan

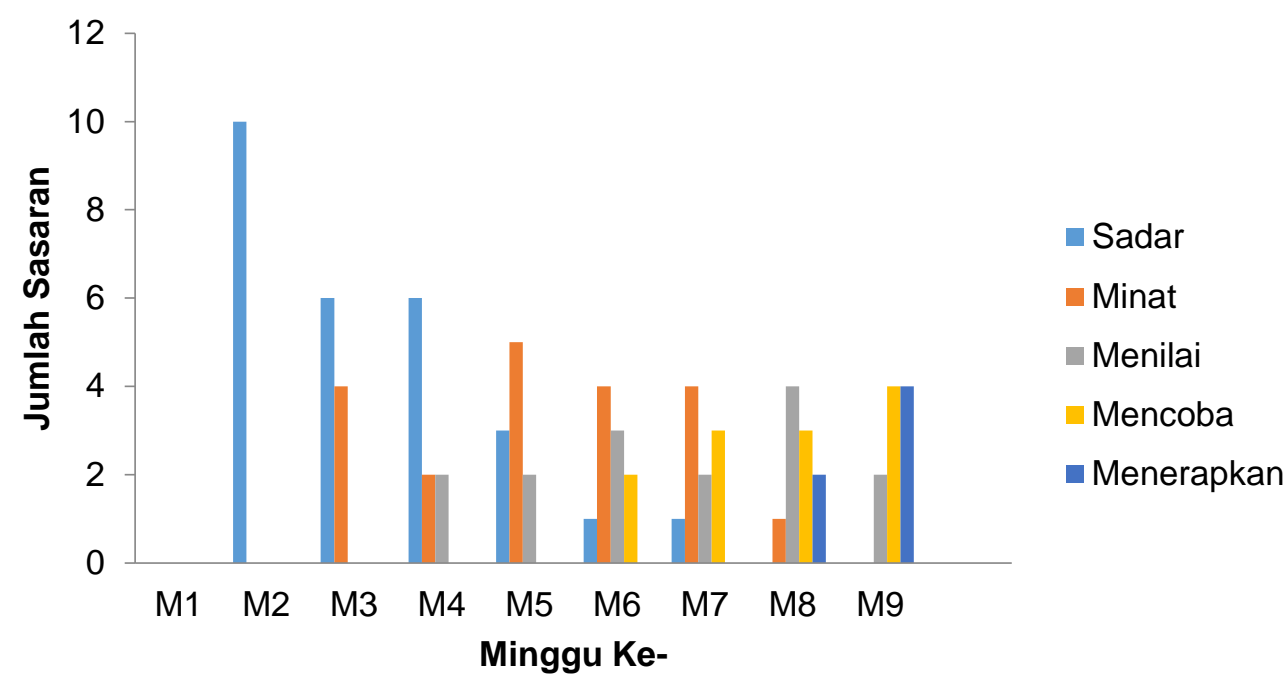

Gambar 8. Tingkat adopsi inovasi probiotik pada pendederan ikan mas

memperlihatkan bahwa telah terjadi peningkatan pengetahuan para responden. Rata-rata responden yang semula skor pengetahuannya 42 meningkat menjadi rata-rata menjadi 87. Peningkatan pengetahuan dapat disebabkan karena metoda penyuluhan yang digunakan. Demonstrasi adalah salah satu cara penyuluhan yang dapat meningkatkan pengetahuan (Astuti, Harta dan Silviyani, 2015). Hasil evaluasi aspek pengetahuan dapat dilihat pada Gambar 5.
Hasil evaluasi aspek sikap menunjukkan pada saat sebelum dilakukan penyuluhan sikap responden berada di angka 31,1 yang berada di antara sikap setuju. Setelah dilakukan dempond pendederan ikan mas dengan probiotik dan non probiotik, nilai sikap responden adalah 44,9. Responden memiliki perubahan sikap ke arah menerima inovasi baru karena skor hasil evaluasi menunjukkan sikap responden sudah mendekati sangat setuju. Hasil evalusi aspek sikap dapat dilihat pada Gambar 7 menunjukkan bahwa evaluasi 
pada aspek keterampilan dilakukan guna mengetahui tingkat keterampilan responden dalam kegiatan dempond pendederan ikan mas. Indikator penilaian pada aspek keterampilan kegiatan dempond pendederan ikan berupa ketepatan, kecepatan dan kecermatan mengenai teknik pendederan ikan mas dan cara pengaplikasian probiotik. Hasil evaluasi keterampilan responden dapat dilihat pada Gambar 7

Hasil rekapitulasi aspek keterampilan mengenai kegiatan dempond pendederan ikan mas menggunakan probiotik diperoleh nilai rata-rata evaluasi awal 13,5 dan terjadi perubahan sebesar 14 sehingga nilai rata-rata evaluasi akhir menjadi 27. Keterampilan responden setelah terlibat pada kegiatan penyuluhan menggunakan metoda dempond pendederan ikan mas menggunakan probiotik, dapat dilihat melalui kemampuan responden dalam melakukan kegiatan pendederan mas dan mengaplikasikan inovasi probiotik yang diberikan.

Selain evaluasi aspek pengetahuan, sikap dan keterampilan juga dilakukan evaluasi dampak atau adopsi inovasi melalui pengamatan secara langsung terkait tingkat penerimaan dan penerapan responden terhadap inovasi yang telah disampaikan dalam rangkaian kegiatan penyuluhan.
Tahap adopsi inovasi pengaplikasian probiotik viterna plus dalam kegiatan dempond pendederan ikan mas dinilai pada setiap minggu, dari minggu pertama hingga minggu ke-9 yang dimulai dari sosialisasi pengenalan probiotik dan kegiatan dempond pendederan ikan mas hingga panen dapat dilihat pada Gambar 8 .

Gambar 8 menunjukkan bahwa tahapan adopsi inovasi responden pada setiap minggu terjadi peningkatan, pada minggu kedua semua responden sudah memasuki tahap sadar. Sebelumnya telah dilakukannya pengenalan mengenai teknologi yang akan diterapkan yaitu probiotik pada pakan ikan mas. Tujuan aplikasi ini adalah untuk mengatasi permasalahan rendahnya produksi pendederan ikan mas dengan biaya produksi yang tinggi di Kecamatan Subang, kemudian pada minggu selanjutnya responden sudah memasuki setiap tahap mengadopsi inovasi probiotik. Minggu kedelapan terdapat dua orang yang sudah menerapkan inovasi yang diberikan setelah melewati beberapa tahap termasuk menilai dan mencoba inovasi dengan berbagai pertimbangannya. Pada minggu ke 9 di akhir kegiatan terdapat 4 orang atau $40 \%$ dari jumlah responden yang sudah menerapkan inovasi pemberian probiotik pada pendederan ikan mas. 


\section{Pembahasan}

Karakteristik pelaku utama sebagai responden penelitian ini perlu diketahui. Hasil observasi menginformasikan bahwa pelaku utama yang bergerak di bidang usaha pendederan ikan mas umumnya berusia 50 tahun dengan tingkat pendidikan sedang yaitu rata-rata lulusan SMA/SLTA. Burhansyah (2014) menyatakan bahwa pelaku utama berada pada usia produktif sehingga kegiatan inovasi yang dilakukan dapat mengandalkan para pelaku utama perikanan untuk mengembangkan inovasi yang diberikan dan juga mampu untuk menerapkannya. Aprilyanti (2017) melaporkan bahwa usia dan masa kerja merupakan faktor yang berkaitan langsung dengan produktivitas kerja sehingga usia produktif 19-50 tahun dapat mempengaruhi kinerja perikanan sehingga kegiatan-kegiatan perikanan mampu untuk diikuti dan diterapkan. Karakteristik sasaran penyuluhan merupakan salah satu faktor yang perlu diperhatikan dalam proses adopsi inovasi. Tingkat adopsi inovasi suatu teknologi dapat dipengaruhi oleh tingkat pengetahuan responden. Faktor lain adalah faktor internal responden yaitu pendidikan, pengetahuan, dan intensitas mengikuti pelatihan/ penyuluhan, dan dapat disebabkan oleh faktor eksternal responden seperti jarak dari rumah lokasi kegiatan/kolam demonstrasi (Astuti, Sugandi dan Hamdan, 2016).

Penelitian adopsi inovasi yang dilakukan yaitu pengaplikasian probiotik dalam pakan, terlihat pada Gambar 1 dan Gambar 2 hasil pengamatan laju pertumbuhan ikan pada kolam A dan kolam B mengalami perbedaan. Probiotik dalam akuakultur didefinisikan sebagai mikroba yang sengaja diberikan menggunakan media pakan maupun media habitatnya yang menguntungkan bagi hewan budidaya (Irianto, 2003). Manfaat penggunaan bahan probiotik juga untuk memperbaiki lingkungan, mencegah terjadi penyakit, memperbaiki sistem pencernaan dan metabolisme ikan, dan membantu ikut meningkatkan jumlah makanan alami dan atau meningkatkan produktivitas (Cruz et al., 2012). Probiotik yang digunakan yaitu probiotik viterna plus yang digunakan pada pakan. Probiotik oral atau yang dimasukan melalui pakan lebih efektif dibandingkan dengan probiotik yang ditambahkan pada lingkungan air kolam (Khatun dan Saha, 2017). Probiotik jenis ini digunakan dengan tujuan untuk meningkatkan nafsu makan ikan sehingga pengaplikasiannya dilakukan melalui pakan (Akter et al., 2017).

Kusumadjaja dan Dewi (2005) menyatakan bahwa kehadiran probiotik dalam pakan dapat membantu dan mempercepat proses pencernaan, 
sehingga nutrien dapat cukup tersedia untuk pertumbuhan dan kelangsungan hidup ikan. Amalia dan Arini (2013) menjelaskan bahwa pertumbuhan ikan yang tinggi dipengaruhi oleh pakan yang tercerna dengan baik akan menghasilkan pasokan energi. Energi yang berasal dari pakan inilah yang digunakan untuk aktifitas tubuh, kelebihan energi digunakan untuk pertumbuhan. Pakan didukung oleh probiotik viterna menjadikan unsur-unsur dalam pakan lebih sederhana akan lebih banyak, dengan unsur-unsur sederhana yang lebih banyak inilah, maka sintesa asam amino untuk menjadi protein tubuh juga lebih besar, sehingga pertambahan bobot akan lebih besar pula.

Tingkat pertumbuhan berat pada pendederan ikan mas menggunakan probiotik terlihat jauh lebih cepat pertumbuhan beratnya dibandingkan yang tidak menggunakan probiotik. Hasil ini sejalan dengan penelitian yang dilakukan oleh Devi, Raza'i dan Wulandari, (2019) yang menyatakan bahwa pemberian probiotik melalui pakan ikan dapat meningkatkan pertumbuhan bobot mutlak (g), pertumbuhan panjang multak $(\mathrm{cm})$, bahkan dapat mengefisiensikan pemberian pakan dan meningkatkan kelangsungan hidup ikan.

Kegiatan demonstrasi pond (dempond) aplikasi probiotik pada pakan pendederan ikan mas diakhiri dengan pemanenan. Pemanenan ini dilakukan pada pagi atau sore hari karena untuk meminimalisir kematian pada saat pemanenen. Pernyataan Fatimah dan Sari (2015) bahwa pemanenan harus dilakukan pada pagi atau sore hari agar ikan tidak mengalami stress akibat suhu yang tinggi selain itu pemanenan dapat dilakukan secara langsung. Benih diangkut dengan menggunakan pengemasan secara tertutup yaitu menggunakan plastik. Fatimah dan Sari (2015) menjelaskan bahwa pengangkutan bisa menggunakan dua cara yaitu dengan menggunakan wadah terbuka dan tertutup.

Perbandingan hasil dempond pendederan ikan mas (Tabel 2), terdapat perbedaan-perbedaan hasil antara kolam A dan kolam B yaitu perbedaan dosis pemberian pakan, FCR. Basahudin dan Arie (2014) menyatakan bahwa pemberian pakan dapat disesuaikan dengan konversi pakan Feed Convertion Ratio (FCR). Pendederan ikan mas memiliki FCR 0,8-1, kolam A karena FCR mencapai 1 , tentunya hal ini lebih menguntungkan dibandingkan dengan FCR kolam B yaitu 1,3. Penggunaan pakan yang rendah pada kolam A karena adanya perhitungan pakan per hari sesuai dengan bobot ikan, persentase pakan, kelangsungan hidup ikan dan jumlah tebar ikan. Penggunaan probiotik 
viterna plus yang dapat mengoptimalkan penyerapan nutrisi pakan pada tubuh ikan.

Kelangsungan hidup ikan mas pada kolam A dan kolam B masih rendah. Tingkat kelangsungan hidup ikan mas pada kolam A hanya $20 \%$, lebih tinggi dibandingkan kolam $B$ yang hanya 15\%. Darseno (2010) melaporkan bahwa tingkat kelangsungan ikan dapat mencapai $80-90 \%$. Ada beberapa faktor yang dapat mempengaruhi tingkat kelangsungan hidup pada ikan antara lain ikan yang ditebar masih sangat rentan yaitu larva berumur 7 hari sehingga jika terbawa arus air saja sudah mati karena masih sangat rentan akan kematian. Beberapa faktor lain yang diduga menyebabkan kolam $A$ mempunyai kelangsungan hidup ikan mas lebih tinggi dibandingkan kolam $B$ adalah pengelolaan pakan yang tidak berlebihan. Penggunaan pakan yang berlebihan menyebabkan kualitas air yang buruk.

Inovasi probiotik yang diberikan pada Kelompok Mina Pojok Jaya dapat diterima dengan baik hal ini dapat terlihat dari hasil evaluasi aspek pengetahuan, sikap, keteramapilan dan evaluasi aspek dampak pada Gambar 5, 6, 7 dan 8 terlihat perubahan-perubahan pada pelaku utama terkait adopsi inovasi yang telah diberikan. Pendapat Kusumawardani (2012) menyatakan bahwa adanya suatu penyuluhan dapat berpengaruh besar terhadap pengetahuan pada kegiatan adopsi inovasi.

Evaluasi aspek sikap juga dilakukan pada kegiatan adopsi inovasi, Fadhilah, Eddy, dan Gayatri (2018) menyatakan bahwa sikap yaitu suatu pikiran dan kecenderungan seseorang yang kurang lebih bersikap permanen mengenai suatu aspek tertentu dalam lingkungannya. Sikap dan pengetahuan sasaran dapat dipengaruhi oleh pengalaman, pendidikan dan lingkungan sasaran. Perubahan sikap sasaran dapat dipengaruhi oleh kegiatan penyuluhan dengan menggunakan metode mengajar yang sesuai untuk mengalihkan pengetahuan dan sikap pembudidaya. Sikap sasaran yang memiliki kategori tinggi berarti sasaran terbuka dalam menerima informasi, inovasi program dan anjuran pemerintah dalam kegiatan usaha budidaya.

Aspek keterampilan responden meningkat setelah dilakukan penyuluhan menggunakan metoda dempond Handoko (2014) menyatakan bahwa keterampilan sasaran penyuluhan yang meningkat dipengaruhi oleh pengalaman sasaran dalam melakukan budidaya. Pengalaman kerja merupakan penguasaan serta keterampilan sasaran yang diukur melalui lamanya dalam melakukan kegiatan budidaya. 
Inovasi probiotik yang diberikan pada Kelompok Mina Pojok Jaya dapat diterima dengan baik oleh responden. Terdapat 4 dari 10 orang responden yang sudah menerapkan inovasi. Strategi untuk mempercepat adopsi inovasi suatu teknologi baru bagi responden atau sasaran penyuluhan dapat dilakukan dengan beberapa cara yaitu (a) memilih inovasi pertanian yang tepat guna (good innovation); (b) memilih metode penyuluhan yang efektif (good extension method); (c) memberdayakan agen penyuluhan secara optimal (good extension agent) (Musyafak dan Ibrahim, 2005).

\section{SIMPULAN DAN SARAN}

\section{Simpulan}

1. Penyuluhan menggunakan metode dempond mengenai teknologi probiotik telah berhasil dilaksanakan di Kelompok Mina Pojok Jaya. Terdapat $40 \%$ responden yang sudah mulai menerapkan inovasi baru yang telah diberikan yaitu penggunaan probiotik pada pendederan ikan mas.

2. Produksi pada pendederan ikan mas menggunakan teknologi probiotik lebih unggul dibandingkan dengan kolam konvensional yang selama ini dilakukan oleh para responden (pembudidaya).

\section{Saran}

Adopsi inovasi dempond pendederan ikan mas menggunakan probiotik ini perlu dilakukan pada kasuskasus lain atau komoditas ikan lainnya sehingga bisa adanya faktor pendukung maupun faktor penghambatnya.

\section{DAFTAR PUSTAKA}

Akter, R., Rahman Md.M., Islam, H.M.R., Islam S., and Ahmed K.K.U (2017) "Role of different types of probiotics in pond ecosystem, in prawn (Macrobrachium rosenbergii) health and production," International Journal of Fisheries and Aquatic Studies, 5(3), hal. 83-87.

Amalia, R. dan Arini, E. (2013) "Pengaruh penggunaan papain terhadap tingkat pemanfaatan protein pakan dan pertumbuhan lele dumbo (Clarias gariepinus)," Journal of Aquaculture Management and Technology, 2(1), hal. 136-143.

Aprilyanti, S. (2017) "Pengaruh usia dan masa kerja terhadap produktivitas kerja (Studi Kasus: PT. OASIS Water International Cabang $\mathrm{Pa}$ lembang)," Jurnal Sistem dan Manajemen Industri, 1(2), hal. 68. doi: 10.30656/jsmi.v1i2.413.

Astuti, U. P., Harta, L. dan Silviyani, E. (2015) "Evaluasi Pelaksanaan penyuluhan terhadap tingkat 
pengetahuan teknologi silase pembuatan pakan ternak di Kecamatan Talang Empat," in Prosiding Seminar Nasional AgroinovasiSpesifik Lokasi untuk Ketahanan Pangan pada Era Masyarakat Ekonomi ASEAN, hal. 989-995.

Basahudin, M. S. dan Arie, U. (2014) Pembesaran lele secara cepat, panen 50 hari. Jakarta (ID): Penebar Swadaya.

Boonthai, T., Vuthiphandchai, V. dan Nimrat, S. (2011) "Probiotic bacteria effects on growth and bacterial composition of black tiger shrimp (Penaeus monodon)," Aquaculture Nutrition, 17(6), hal. 634-644. doi: 10.1111/j.13652095.2011.00865.x.

Cruz, P. M., Ib'ãnez, A.L, Hermosillo, O.A.M., and Saad, H.C.R. (2012) "Use of probiotics in aquaculture," International Scholarly Research Network licrobiology, 2012 (October) hal. 1-13. doi: 10.5402/2012/916845.

Darseno, S. P. (2010) Buku pintar budi daya dan bisnis lele. Jakarta (ID): AgroMedia.

Fadhilah, M. L., Eddy, B. T. dan Gayatri, S. (2018) "Pengaruh tingkat pengetahuan, sikap dan keterampilan penerapan agribisnis terha- dap produksi pada petani padi di Kecamatan Cimangga Kabupaten Cilacap," Agrisocionomics: Jurnal Sosial Ekonomi Pertanian, 2(1), hal. $39 . \quad$ doi: 10.14710/agrisocionomics.v2i1.13 27.

Fatimah, E. N. dan Sari, M. (2015) Kiat sukses budidaya ikan lele. Depok (ID): Bibit Publisher.

Hanan, A. (2017) “Difusi adopsi teknologi pendederan ikan patin pada kelompok pembudidaya ikan di Kabupaten Purwakarta," Jurnal Penyuluhan Perikanan dan Kelautan, 11(1), hal. 1-11. doi: 10.33378/jppik.v11i1.81.

Handoko, T. H. (2014) Dasar-dasar manajemen produksi dan operasi. Yogyakarta (ID): Badan Penerbit Fakultas Ekonomi.

Irianto, A. (2003) Probiotik akuakultur. Yogyakarta (ID): Gadjah Mada University Press.

Iribarren, D., Daga' P., Moreira M.T., Feijoo G. (2012) "Potential environmental effects of probiotics used in aquaculture," Aquaculture International, 20(4), hal. 779-789. doi: 10.1007/s10499-012-9502-z.

Khatun, M. dan Saha, S. (2017) "Effect of different probiotics on growth, survival and production of monosex nile tilapia (Oreochromis niloticus 
)," International Journal of Fisheries and Aquatic Studies, 5(1), hal. 346-351.

Kusumadjaja, A. P. dan Dewi, R. P. (2005) "Determination of optimum condition of papain enzyme from Papaya Var Java (Carica papaya)," Indonesian Journal of Chemistry, 5(2), hal. 147-151. doi: 10.22146/ijc.21822.

Kusumawardani, E. (2012) Pengaruh penyuluhan kesehatan terhadap tingkat pengetahuan, sikap dan praktik ibu dalam pencegahan demam berdarah dengue pada anak [Skripsi]. Universitas Diponegoro.

Mansyur, A. dan Tangko, A. M. (2008) "Probiotik: pemanfaatannya untuk pakan ikan berkualitas rendah," Media Akuakultur, 3(2), hal. 145149.

Musyafak, A. dan Ibrahim, T. M. (2005) "Strategi percepatan adopsi dan difusi inovasi pertanian mendukung prima tani.," Analisis Kebijakan Pertanian., 3(45), hal. 20-37.

Ningsih, N., Nalefo, L. dan Wunawarsih, I. A. (2019) "Efektivitas metode kelompok terhadap peningkatan pengetahuan wanita tani dalam pemanfaatan lahan pekarangan di Desa Kalimas Kecamatan
Kaledupa Kabupaten Wakatobi," Jurnal Ilmiah Membangun Desa dan Pertanian, 4(2), hal. 52-56.

Primaningtyas, A. W., Hastuti, S. dan Program, S. (2015) "Performa produksi ikan lele (Clarias gariepinus) yang dipelihara dalam sistem budidaya berbeda," Journal of Aquaculture Manage-ment and Technology, 4(4), hal. 51-60.

Putri, F. S., Hasan, Z. dan Haetami, K. (2012) "Pengaruh pemberian bakteri probiotik pada pelet yang mengandung kaliandra (Calliandra calothyrsus) terhadap pertumbuhan benih ikan ila (Oreochromis niloticus)," Jurnal Perikanan Kelautan, 3(4), hal. 283-291. 